\title{
2. Fiji 2000: Journalists and the George Speight coup
}

\begin{abstract}
ABSIIRACI
Much criticism of both the local and international media's role during the May 2000 coup in Fiji emerged after the crisis. Critics included editors and journalists of the local and international media and political and historical analysts who knew the 'real reasons' behind the coup and did not see this being reported. This article analyses interviews with 17 journalists, 13 local four foreign reporters, who covered the coup, and their reaction to criticisms made against them over coverage. It also assesses possible effects on some journalists by the so-called Stockholm syndrome because of their close association with businessman George Speight and his fellow captors who held the Mahendra Chaudhry government hostage for 56 days.
\end{abstract}

CHRISTINE GOUNDER

Pacific Radio News (Niu FM and 531pi), Auckland

\section{Introduction}

T 10.45am on the morning of Friday, 19 May 2000, after one year in office, the democratically elected Fiji Labour Party-led government
was taken hostage in a coup d'état led by a bald-headed businessman George Speight and six gunmen. Until then George Speight had been largely unknown as a public figure, except for allegations of fraudulent business allegations against him.

Journalists have dubbed Fiji 'coup coup land' because of the four coups it has encountered within a span of two decades. Fiji's population of about 840,000 is approximately 49 percent indigenous Fijians and 46 percent Indo-Fijians who are mostly descendants of indentured labourers brought from the Indian subcontinent to work on sugar plantations in the 19th century.

The first coup in Fiji took place on 14 May 1987 when the democratically elected government was overthrown after only one month in power. Longstanding racial tensions between the two major races were blamed as the reason for the coup. The first coup was covered mostly by the international media 
because the Fiji media were barred from reporting fairly. Fiji journalists faced threats by coup leader Sitiveni Rabuka's regime as well as a lack of necessary resources to back them up. The second coup, also staged by Rabuka, was on 25 September 1987.

The third coup, 13 years later, took place on 19 May 2000 and was led by an Australian permanent resident who claimed to fight for indigenous rights, George Speight. A fourth coup was staged on 5 December 2006 by the military commander, Commodore Voreqe Bainimarama, to 'clean up' the 'corrupt' legacy left by the Speight coup.

The 2000 coup came as a surprise for the media because it was a different type of coup. For the first time, perhaps in the history of coups, the hostage takers were readily accessible to the media and provided them with information through press conferences and personal interviews. However, even with this information overload, the press still made blunders and published inaccurate reports.

During the 1987 military coup, Rabuka closed down the media and controlled the news broadcasts over the government-owned radio station, Radio Fiji. In 2000, instead of refusing to speak to the media, George Speight made himself available without delay and he loved the media just as they loved him. He held numerous press conferences for instance and allowed the media to walk freely in and out of Parliament. When the military set up a roadblock outside Parliament and did not allow anyone to go in, George Speight walked down the road and told them to allow the journalists in. The internet also played a role in influencing how information was communicated to the rest of the world. Speight was a character who treated the media as his friends. In the race to get the best story first, the media often became his propaganda arm.

After the May 2000 coup, much discussion centred on whether the media did a good job covering the crisis or whether it was 'swept away by the euphoria of the moment' (Moala, 2001). Limited research has been done to evaluate the numerous criticisms against the media (see Field 2000, 2005; Moala 2001; Robie, 2000, 2001, 2004; Thaman 2001; Chaudhry 2001). This article, part of a wider research project into coverage of the coup, examines the major print media through interviews with journalists in Australia, Fiji and New Zealand.

\section{The Stockholm syndrome}

The Stockholm syndrome describes the behaviour of kidnap victims or 
people who associate closely with the captors, and who over time become sympathetic to their captors. The syndrome is derived from a 1973 hostage siege in Stockholm, Sweden, when at the end of six days of captivity at a bank, several kidnap victims actually resisted rescue attempts, and later refused to testify against their captors. During the Fiji 2000 coup, apart from Speight's supporters, journalists were the only ones who spent a lot of time with the coup leader either at press conferences or staying at Parliament to get good stories. As a result, some journalists began to 'sway' towards Speight or began to experience the Stockholm syndrome. This was reflected in their stories.

\section{Methodology}

Seventeen journalists and editors - 13 local and four foreign reporterswere asked to discuss their experiences while reporting during the 56 days that the Chaudhry government was held captive. The aim of the qualitative interviews was to:

- Assess any impact of the Stockholm syndrome on the journalists

- Gauge whether the journalists were prepared for covering the coup

- Assess whether they were harassed or threatened

- Examine difficulties encountered in covering the coup

\section{The narrative}

\section{First day impressions}

All local media were covering a protest march against the Chaudhry government on 19 May 2000 and did not expect the takeover at Parliament even though they had heard rumours that a coup attempt was close. As soon as news of the coup broke, journalists rushed to Parliament to get a first-hand account of what was going on. The Fiji Broadcasting Corporation (FBC) was the first to break the news of the coup as the live feed from Parliament in their studios heard the commotion and conversation between the rebels and the Speaker of the House.

Tamani Nair, who was doing his journalism attachment at the FBC in Suva, was sitting in the newsroom when he heard a commotion on the parliamentary live feed. As soon as he heard the Speaker of the House saying to Speight, 'what's going on', he knew something was wrong (T. Nair, interview, 11 August 2005).

At the FM96 newsroom, May 19 was supposed to be last day at work for news editor Virisila Buadromo. On that day FM 96 was planning to launch 
its new website, www.fijivillage.com. Buadromo thought the biggest story of the day was going to be the march so she was constantly updating the website with pictures of the march and stories (V. Buadromo, interview, 10 August 2005). At $10.45 \mathrm{am}$, a government minister called Buadromo's source and said some people had walked in and stormed Parliament. By the time the FM96 reporters rushed to Parliament, the gates had been shut and people with guns were seen walking around.

Malakai Veisamasama, a reporter for FM96, was following the march when he got the 'phone call'. He rushed to Parliament, but by the time he got there the gates were shut (M. Veisamasama, interview, 8 August 2005).

Tukini Cama, a radio personality with FM96, was also sent by Buadromo to cover the march. As the march approached the President's house, another journalist whispered what had happened at Parliament to Cama. However, they kept this news to themselves and only told the Assistant Police Commissioner, Romano Tikotikoca, who was also keeping an eye on the march. Cama got a ride with friends he saw at the Holiday Inn to Parliament. He saw weeping women and distraught students, who had been inside Parliament during the takeover, standing outside and a balaclava clad man dressed in black holding an M16 guarding the gates (T. Cama, interview, 16 August 2005).

Fiji Television reporter Riyaz Sayed-Kaiyum was also following the march. He, too, had heard rumours that there was going to be some sort of 'unrest' but did not expect anything like what happened. When people back at the television station advised him about the armed takeover, he too rushed to Parliament and tried to talk to the hostage takers through the fence but was told to 'piss off'. He managed to get an interview with Speight that night but something told him not to go back (R. Sayed-Kaiyum, interview, 11 August 2005).

While sitting at a funeral at the Methodist Church in the middle of the city, Francis Herman, general manager of the FBC, had to leave abruptly when the police came in to tell him about the takeover at Parliament. Fortunately for Herman, his team of 22 journalists were prepared for a possible coup and had been planning how they would cover it for months (F. Herman, interview, 18 August 2005).

\section{Staying over at Parliament}

While some of the local and overseas journalists interviewed did not think it was wrong to stay over at Parliament, or that this could jeopardise their reporting; others disagreed. 
Because George Speight often held press conferences in the middle of the night, most of the journalists did not want to be left out and stayed at Parliament, according to Nair. He described the atmosphere inside as 'tense'. Staying at Parliament then was the 'in-thing' to do, to be where the action was. Nair regretted staying and being fed by the rebels when he later realised that the media was being used as propaganda to get supporters into Parliament.

Veisamasama and Cama also stayed at Parliament. Veisamasama, who is of chiefly status, had many relatives supporting Speight and staying over at Parliament and he did not have any problems with access, or with accommodation and food. Cama and Veisamasama were seen by their news editor Buadromo drinking kava with Speight . Cama admitted that, because he was being treated by the rebels as 'one of them', at times they forgot he was from the media.

Former FBC reporter Samisoni Pareti shared his lunch with George Speight and went on air to say 'the coup leader had a taste for food cooked by FBC' (Herman, interview, 18 August 2005). General manager Francis Herman admitted this was a huge mistake as it questioned the credibility of the radio station and suggested that $\mathrm{FBC}$ was providing food to the rebels. The rebels on the other hand were offended by this comment because their interpretation was that there was no food inside Parliament. The comment by Pareti had to be clarified on air in three languages.

Only one out of the four overseas journalists interviewed stayed over at Parliament. Senior journalist Phil Taylor at The New Zealand Herald stayed over for only one day to get 'insight into what was going on' and this enabled him to 'observe Speight'. Taylor disagreed that this caused him to favour Speight as he was there only for a day (Taylor, interview, 20 September 2005).

Australian Broadcasting Corporation journalist Sean Dorney reported on the coup from Australia and would have stayed in Parliament had he been in Fiji because 'that was where the story was' (S. Dorney, interview, 7 September 2005).

However, interviews with journalists (Gounder, 2006, pp. 98-177) showed that staying at Parliament for more than a day was probably not a good idea. Some admitted being affected by the Stockholm syndrome and began to support the rebels. Others would have also been affected if they had stayed longer inside. 


\section{'Supporting' Speight}

Radio host Tukini Cama was briefed along with others in an hour to report on the coup by FM96 news editor Virisila Buadromo. He was one of the journalists accused of supporting Speight, an allegation he denied when interviewed (T. Cama, interview, 16 August 2000). According to Cama, the speculation about his role all started when Speight announced at a press conference that Cama was his media liaison officer. This, he said, was done maliciously by Speight to embarrass Cama. However, Buadromo noticed that Cama ran long reports on Speight from Parliament and she saw he had started to support Speight in his stories. She stopped him from going live and had his news recorded half an hour before going to air so that she could edit his news. Buadromo did the same to every reporter after she realised that they could also be suffering from the Stockholm syndrome.

Veisamasama, who had a stepbrother and many of his relatives inside Parliament supporting Speight, admitted he had suffered from the Stockholm syndrome. According to Veisamasama the close family ties meant he was in constant conversation with his relatives and they kept saying that Speight was right and it started to sink into his mind that they might be correct. 'It was like walking in a straight line for 10 days and losing one's balance after a while' (Veisamasama, interview, 8 August 2000). Veisamasama was in Parliament on and off during the 56 days of the coup and stayed over for 20 days. He slept wherever he could sleep. Veisamasama did not feel scared because he 'had his relatives around him'. Communications Fiji Ltd general manager Ian Jackson said when they noticed Veisamasama 'swaying', they pulled him out to take regular breaks from Parliament. The different atmosphere helped Veisamasama begin to think clearly.

Josua Tuwere, a reporter for The Fiji Times during the coup, found himself being more sympathetic towards Speight near the end of the hostage crisis. While staying at Parliament, he remembered thinking how great it would be to have a gun in his hand. Chief-of-staff Akanisi Motufaga also stayed over at Parliament with some of her reporters, however, to avoid the problem of bias, no single Fiji Times reporter stayed two consecutive nights at Parliament.

\section{Harassment and threats against journalists}

Most of the journalists interviewed did feel scared or were harassed and threatened during the 56 days of the crisis.

Buadromo got scared when she went to Parliament and Speight would not 
let her go after she interviewed him. Apparently there had been a 'lockdown' and there was talk that the military was going to stage a raid. Buadromo who was very nervous by this time, because she did not want to get caught in a crossfire between the military and the rebels, told Veisamasama (who was drinking kava with Cama and the rebels) to tell the rebels if they let her out she would buy them a 'whole lot of kava'. Speight and Jo Nata, Speight's official public relations man who was a former journalist and later jailed for treason, told Buadromo to relax and assured her she would get out soon. She and the other reporters were released an hour and a half later.

Sayed-Kaiyum thought he should never have gone to Parliament from the first day as advised by the President of Fiji, Ratu Sir Kamisese Mara. However because the local media did not want to miss the story and the overseas media had ignored the President's advice, it was a race to get the story at any cost even if it meant talking to the hostage takers. Sayed-Kaiyum felt threatened the first day he interviewed Speight. Two weeks later he was also verbally threatened in the middle of the night and objects were thrown at the house he stayed at. Even though the police were called in, it was a very frightening time for Sayed-Kaiyum and his family, which included a newborn baby. Sayed-Kaiyum was also threatened the night after Fiji Television was trashed on May 28 following a Close Up programme presented by him in which the rebels were strongly criticised. He fled to the western side of Fiji with only twenty cents in his pocket. He made his way back home a few days later when he thought it was safe.

Fiji Times reporter Raijeli Kikau felt threatened on the third week of the crisis when the local media were taken hostage on a Wednesday evening after a press conference. They were told that there was a bomb threat in the Parliamentary complex and no one was allowed to leave until it was safe. They were provided dinner and told to wait in one of the rooms, in the same complex where the Labour parliamentarians were held hostage. However, Kikau was confident that if the media were taken hostage, they would survive by encouraging each other as they had formed a small media family inside the complex who looked out for each other.

According to Cama, he was harassed twice by Speight's supporters who felt that he was a spy for the outside world. This stopped when he told Speight and they were told to leave the media alone.

Fiji Sun reporter Jone Kalouniviti felt threatened from the first time he 
entered Parliament. Kalouniviti realised there was no law and order and everyone was at the mercy of the rebels. The atmosphere inside Parliament was tense and he remembered the 'hair on the back of my neck' standing during the first press conference. However, as the days rolled on, he took comfort in the presence of his 'grandfather', one of the supporters inside Parliament. Everyone came to know him as his grandson and left him alone.

Veisamasama got beaten the night Fiji Television was trashed on May 28. Veisamasama was locked up in a room with the other journalists while a security camera watched what they were doing. He covered the security camera with a cloth and got hit for doing that. He then pleaded with one of the rebels to pass a message to his stepbrother and to George Speight asking them to release the foreign and female journalists who were locked up. When the message got to Speight, he released the forign media first.

Daily Post assistant editor Mesake Koroi still remembers the day his life was threatened. As armed thugs marched from Parliament down Nasese Road to the military checkpoint, Koroi and his reporters stood shocked and dazed as they tried to think of a quick action to save themselves from the crossfire as they were standing under a tree in between the checkpoint and the rebels. In the bushes behind them were about 500 soldiers camouflaged and ready to shoot at the rebels if they tried to force their way past the checkpoint. In his fright, Koroi climbed to the top of the nearest tree to hide. Luckily, there was no shooting because the rebels resisted.

Motufaga felt threatened when a photographer was beaten because he was mistaken for a policeman. The mood of the mob was 'fickle and quick to anger' and she feared for herself and the safety of her reporters

Phil Taylor, of The New Zealand Herald, had to use his own discretion about whether he should go to certain places at the parliamentary complex to gather information and found himself constantly evaluating whether it was safe. Even though he was not threatened directly, he was aware of the volatility of the situation and was present during the shoot-out between the rebels and the military which left one soldier and a cameraman shot.

TVNZ's Ewart Barnsley felt threatened every time he went to Parliament and especially when a policeman was murdered on the night Fiji Television was trashed on May 28. He left Suva along with many other journalists on May 29 but returned the next day when the military took control.

Similarly Michael Field from AFP was troubled with the Fiji Television 
trashing and became upset for close friends who lived in Fiji. Field got seriously ill at one stage during the coup and felt he could have been hurt at any time.

Race and risk

Indo-Fijian reporters seemed to be put under more pressure than to Fijian reporters. This may have been because they were Indian and the coup was supposedly against Indians; people were harsh and uncooperative to them. Nair was afraid that he was part-Indian while he was inside Parliament.

...I did not want to be identified as Indian because there were a lot of racial tension and anti-Indian sentiments floated around and you wouldn't want to be caught in that because anything could have happened (Nair, interview, 11 August 2005).

Nair never gave his surname whenever he was asked as he would have been identified as an Indian name. Similarly Buadromo did not allow any of her Indo-Fijian reporters to go to Parliament, they were all based in the office.

I rejigged our roster; I pulled all the Indo-Fijian reporters off, I really didn't know what to expect. [I put on] only male reporters to cover the march and only Fijian reporters (Buadromo, interview, 10 August 2005).

According to Buadromo, many Indian members of the community started calling up the Indian radio station because they heard that the coup was a race issue. She admitted that she was confused during the first week whether the coup was really race-based or was motivated by something else.

Josephine Prasad of the Daily Post was worried about her safety when Speight and his men stormed Parliament. She was in the media chambers when the coup took place.

The media had their war with the People's Coalition Government — but democracy is what every journalist should uphold and it being raped before my naked eyes was a traumatic experience and challenging as a journalist (J. Prasad, interview, 20 September 2005).

According to Prasad, a gun was shoved up her spine and she could not 
sleep on her back for weeks and 'every time I tried to sleep I could see $\mathrm{Mr}$ Chaudhry being kicked or a warrior cry if my phone would ring' (Prasad, interview. Prasad was a state witness for court cases to identify the men that accompanied Speight on 19 May has suffered abuse since.

My life has since been threatened. I remember Speight (or someone pretending to be him) calling me on several occasions not happy with what I had written during the coup period.

Prasad's abuse was monitored by Amnesty International. Veisamasama agreed that it was too risky for the Indo-Fijian reporters to go to Parliament or be seen there.

They were targeting the Indian journalists inside and when they pulled out Asha Lakhan (AFP) I got worried for my two Indian colleagues with me and for myself as well (Veisamasama, interview, 8 August 2005).

According to Veisamasama as a result of the risk, a decision was made that 'the Indian reporters would not go out into the streets and would stay within the building'. Koroi knew that the Indian community were being targeted after Suva city was trashed. So he sent his entire Indian staff home and did not allow them to work.

\section{Training/education of journalists}

Most of the local journalists interviewed did not have any formal journalism qualification when they were hired (see Robie, 2004, pp. 203-238; Robie \& Singh, 2004) for research on qualifications). Akanisi Motufaga did not study journalism because there was no journalism course in 1994. However, she was trained on the job for the first three years and also attended workshops conducted by the Fiji Islands Media Association (PIMA) every three months. Jone Kalouniviti came straight out of high school and was also trained on the job when he joined the Daily Post in 1999. Like Motufaga, he also attended workshops conducted by an expatriate training manager hired by his newspaper. However, after six years, he enrolled at the journalism programme at the University of the South Pacific.

Josephine Prasad began her journalism career as a supplements writer 
for the Daily Post on a casual basis earning $\$ 60$ a week. She was also trained on the job and does not have any formal qualification in journalism. Josua Tuwere was an English and history teacher at Marist Brothers High School in Suva in 1994 before he joined FM96 radio station's news department. He was trained in-house with a Canadian consultant who focused on voice modulation, script writing and on-the-scene reporting. Tuwere later joined the Fiji Times and was trained again on writing for newspapers.

Mesake Koroi was trained to be an agriculturalist and not a journalist. While looking for a job there was an opening in the ethnic Fijian newspaper, Nai Lalakai, which he applied for and got. He enjoyed it so much he decided to stay and has now been in journalism for 35 years.

Raijeli Kikau never thought she would 'end up writing'. Kikau was more interested in economics and accounting. She was studying history/politics at USP when she heard an advertisement on radio calling for reporters. She applied and was accepted. Kikau was also trained 'in-house'. She then enrolled in the Diploma for Pacific Journalism programme at USP.

Riyaz Sayed-Kaiyum also 'fell into' journalism by accident. He always had an interest in writing and telling stories and journalism seemed like the only thing 'I could fall into after giving up studies in accounting'. Sayed-Kaiyum started as a disc jockey for FM96 in 1993 before joining Fiji Television. He too was trained in-house and attended courses conducted by FIMA.

Tamani Nair studied technology at USP for a year before he was able to convince his father that he wanted to do journalism. He studied journalism at university for three years before he was offered a job with the FBC.

Tukini Cama was still in high school when the 1987 coup happened. He saw how important journalism was during the coup and decided to go into journalism. At university, he studied communications as a minor as 'journalism wasn't even at school back then'. He joined the programme department of FM96 in 1990 and was a popular host of the Breakfast Show. According to Cama, he was called now and then by the news department to report on news events whenever there was 'pressure on reporters'.

Virisila Buadromo never considered herself as a journalist but as a reporter because 'I thought I was reporting what was going on' and because there 'was very little analysis at the time'. After studying at university she wanted to do something that 'would come naturally to me like talking to people'. So she got involved in radio broadcasting and worked for FM96 for nine years starting off as a cadet reporter. 
All of the foreign journalists interviewed had undergone journalism training at a tertiary institution. The interviews reflected that journalists who had undergone professional journalism training and education performed better in their role. They not only had the ability to write balanced, analytical and investigative stories but also seemed to understand issues better and were familiar with the codes of journalism ethics and media law.

\section{Journalistic professionalism during the coup}

Most of the journalists, both local and overseas, thought they were professional in their jobs during the coup and few regretted their actions or stories they wrote during the coup. Akanisi Motufaga tried hard not to show favour or disgust in her stories and in her view, always presented balanced stories. She left all commentary to the editorial comment section.

I always evaluated the position, [the] angle of stories (to ensure it wasn't slanted). [I] reported the facts and left it to the readers to make up their minds. I never fraternised with Speight and company (Motufaga, interview, 6 September 2005).

Even though Motufaga did not regret writing any story during the coup, if given another opportunity, she would not spend too much time focusing on what was happening in Parliament and in the city. The New Zealand Herald's Eugene Bingham thought the same but said that 'ultimately that is for others to decide'.

I attempted to write stories which were fair, accurate and balanced and written with context (Bingham, interview, 13 September 2005).

Ewart Barnsley believed he acted professionally by 'not taking sides... keeping a personal distance from all sides... and making sure my stories were balanced' (Barnsley, interview, 7 September 2005). Barnsley does not regret writing anything he reported on-even though one prominent businessman close to Speight objected to a story reporting that police were reportedly investigating several prominent businessmen for allegedly backing Speight with money. He did not name anybody, but reported those on the police list included people from the Indian and Chinese communities. A businessmansued TVNZ for libel and the case was settled out of court. However, 
according to Barnsley, his work during the coup was acknowledged when he won New Zealand's TV reporting prize that year.

Former AFP South Pacific correspondent Michael Field did his best to remain professional but ackowledged that everyone was human.

I am pretty human too; never compromised myself but had to accommodate myself to all the various local difficulties and complications. It was why I was pretty well paid—you spend your entire time in various balancing acts (M. Field, interview, 20 June 2005).

His biggest regret was writing numerous stories suggesting that resolution was near.

Inever believed it would last long. I am always conscious that news stories are written on the trot, under pressure and sometimes with only an outline of the facts - and often (certainly in Fiji) without any way of checking (Field interview).

If there was anything he would change about how he went about reporting the coup, it would be taking more time out 'because at various points I found myself physically tired and mentally exhausted' (Field, interview).

Raijeli Kikau admitted that it was hard for her to remain professional because it was the first time for her to see men holding guns and wearing balaclavas.

But it never dictated how I had to write what was happening inside and I kept to that stand even though some days they took my mobile phone, bag and tape recorder and told me to sit outside the complex for an hour before being allowed in if I wrote something they thought was against the cause (R. Kikau, interview, 7 September 2005).

\section{'Parachute journalism'}

While some journalists and editors interviewed said the local and foreign media complemented each other during the coup, others said the overseas media did a bad job at reporting and made matters worse by not understanding the main issues and sensationalising events.

Eugene Bingham, of the New Zealand Herald, said the international coverage of the coup was important in bringing foreign attention to the crisis 
and because overseas media organisations had to 'scramble staff' to send to Fiji, it was natural that they were unprepared.

I'm sure there are many examples of shoddy journalism practice by those who may be termed 'parachute journalists' but I also think that there was some fine reporting of the coup by overseas journalists (Bingham, interview, 13 September 2005).

According to Eugene Bingham, in the end it was up to media organisations to improve their knowledge of the Pacific and some had already started assigning special reporters to cover Pacific affairs.

But at the same time I think it is sad that some of those who criticise media coverage of the Pacific are people who could instead be using their energy actually reporting on the Pacific (Bingham interview).

Ewart Barnsley said the local Fijian media seemed to do a pretty good job 'although given Fiji's size and family ties some appeared too close to Speight and his cronies to be objective'.

I think the journalists and other staff at Fiji TV are among the bravest people I have ever met (Barnsley interview).

Jone Kalouniviti criticised the foreign media for 'sensationalism and exaggeration'.

The local media did a better job because they printed the real picture (Kalouniviti interview).

However, Josephine Prasad believed every journalist did what was required of them and international journalists such as Michael Field and Sean Dorney were well versed with Fiji politics and were helpful to the local media and vice versa. She agreed that some overseas journalists who sensationalised the crisis.

I remember while at the Centra, how one international journalist spun the windmills of gossip and the whole bang lot of them went into frenzy trying to pack up and leave as they were told there was a group 
of rebels on the way from Parliament to mob the hotel just days after Fiji One was mobbed (Prasad interview).

Josua Tuwere remembered how the local journalists were amazed at the equipment the overseas journalists had - satellite phones, expensive laptops, zoom lens cameras, TV cameras and booms. Thatcaptured somerealmemorable momentsand theoverseasmediaprobablybroughtawholenewdimension to efficiencyandgettingthenewstothepeople(Tuwere, interview, 15November2005). According to Mesake Koroi, the foreign journalists were looking for lootings, fights and mass killings 'like those in South Africa'.

They were trying to pick on small things. But when it didn't happen that way they started to pick on little instances like that. They know nothing about the culture, they know nothing about the cosmopolitan society that we have. They just thought that this is just one great big disaster (Koroi interview).

Koroi thought the local media did a better job and gave a better perspective of what was happening but the foreign media could not be blamed as 'they don't know the place and country and reported whatever they saw'. In future, Koroi suggested the issue of parachute journalism could be solved through preparation and research by the journalist.

It boils down to a journalist's preparation. A lot of information is available through the internet now and journalists can do research and study a country before they go in (Koroi interview).

Sean Dorney said that maintaining an office in Fiji could be a solution for overseas media to avoid parachute journalism. However, the costs of maintaining an office and correspondents were too high.

The Australian media, as a whole, takes very limited interest in the Pacific so almost nobody has a local stringer. That is a problem because when crises like this happen they send people who know nothing. The big advantage for the parachute journalists who know nothing is having bosses and subeditors who know less. So there is no quality evaluation of copy (Dorney, interview, 7 September 2005). 
Dorney said he was the only working journalist in Australia who visited the Pacific regularly and Australian news media remained 'woefully ignorant' about the region.

\section{Conclusion}

It was difficult for many Fijian journalists to remain professional in their jobs because of the strong cultural ties with the supporters of George Speight's coup. Most admitted suffering from the Stockholm syndrome. Many of the overseas journalists on the other hand were labelled 'parachute journalists' by the local media in Fiji. While a few local journalists commended the investigative reports of these 'parachute journalists', others said they did not understand the complexities of Fiji's political situation.

Fiji is very crisis prone and now we have seen this tiny island nation go through its fourth coup in two decades. A precedent seems to be set and whenever someone or the army is not happy with the government, they stage a coup. Many experienced journalists and editors have migrated, taking with them the institutional knowledge and leaving behind a mostly inexperienced and young newsroom. Perhaps a crisis manual could help these young reporters learn how to deal with crisis reporting and learn from the mistakes of past journalists. Even though no crisis situation would be the same, the guidelines would be basic and could be recorded as case studies by different journalists from different media organisations with the mistakes they made and how this could be avoided in future. Guidelines such as not staying over in Parliament for too long but taking regular breaks, avoiding words that would give credibility and legitimacy to the hostage-takers and not giving supporters or anyone connected to the rebels a voice on radio. The foreign media, on the other hand, should avoid parachute journalism and inaccurate reporting (due to a failure to understand the culture and complex political systems). They could do this by attaching themselves to local media outlets. They would be able to verify facts and any misconceptions or misunderstandings of the culture with local journalists through such an attachment.

Interviews with journalists and editors who covered the 2000 coup

1. Barnsley, E., emailed interview, 7 September 2005.

2. Bingham, E., emailed interview, 13 September 2005.

3. Buadromo, V., audiotaped interview, 10 August 2005.

4. Cama, T., audiotaped interview, 16 August 2005

5. Dorney, S., emailed interview, 7 September 2005

6. Field, M., emailed interview, 20 June 2005.

140 PACIFIC JOURNALISM REVIEW 13 (1) 2007 
7. Herman, F., audiotaped interview, 18 August 2005

8. Kalouniviti, J., emailed interview, 7 September 2005.

9. Kikau, R., emailed interview, 7 September 2005.

10. Koroi, M., audiotaped interview, 8 August 2005.

11. Nair, T., audiotaped interview, 11 August 2005.

12. Prasad, J., emailed interview, 20 September 2005.

13. Sayed-Kaiyum, R., emailed interview, 11 August 2005.

14. Taylor, P., audiotaped interview, 20 September 2005.

15. Veisamasama, M., audiotaped interview, 8 August 2005.

16. Motufaga, A., audiotaped interview, 6 September 2005.

17. Tuwere, J., emailed interview, 15 November 2005.

\section{References}

Chaudhry, M. (2000). Fiji news media faces crisis of ethics. Pacific Journalism Review, 6 (1): pp.135-146.

Field, M., Baba, T., and Nabobo-Baba, U. (2005). Speight of violence: inside Fiji's 2000 coup. Auckland: Reed Publishing.

Field, M. (2000). Clueless in coup, coup land. The Fiji Times, June 30, p. 7.

Gounder, C., (2006). The Fiji 2000 coup: a media analysis. Unpublished MA thesis. Auckland: School of Communication Studies, AUT University.

Moala, J. (2001). Copy versus custom. Pacific Journalism Review 7(1): pp. 29-34.

Robie, D. (2004). Mekim nius: South Pacific media, politics and education. Suva: University of the South Pacific Book Centre.

Robie, D. and Singh, S. (2004). From campus to newsroom in the South Pacific: governance and the quest for a professional journalism ethos. Fijian Studies, 2(2): pp. 245-268.

Robie, D. (2001). Coup coup land: the press and the putsch in Fiji. AsiaPacific MediaEducator, No 10: pp. 148-162.

Robie, D. (2000). Taukei takeover: the media anatomy of a coup. Australian Journalism Review., 22(2): pp. 1-16.

Thaman, K. (2001). Reclaiming Pacific images: a view of communication and peace. Paper presented at an International Association for Mass Communication Research (IAMCR) conference, Budapest, September 6-10. Cited in Robie, D. (2004), Mekim nius: South Pacific media, politics and education (p. 47). Suva: USP

Christine Gounder is a Fiji-born journalist now working with PacificRadioNewsNetwork. Anearlierversionof this article,partof herMAin Communication Studies research at AUTUniversity, was presented at the Second Joint Journalism Education Association (JEA) and Journalism Education Association of New Zealand (JEANZ) conference in Auckland, 4-6 December, 2006.

christine.gounder@niufm.com 
Copyright of Pacific Journalism Review is the property of Auckland University of Technology and its content may not be copied or emailed to multiple sites or posted to a listserv without the copyright holder's express written permission. However, users may print, download, or email articles for individual use. http://www.aut.ac.nz/depts/commstud/journ/pjrsubs.shtml 